\title{
New guidelines on depression from NICE
}

Ruth I Ohlsen

From $1^{\text {st }}$ International Congress on Neurobiology and Clinical Psychopharmacology and European

Psychiatric Association Conference on Treatment Guidance

Thessaloniki, Greece. 19-22 November 2009

In September 2009, NICE will publish two new guidelines in the field of depression - depression in adults and depression in chronic physical health problems. The guideline on depression in adults includes major changes to current prescribing practice. The most important of these is the recommendation that antidepressants drugs are switched if there is no response after three to four weeks. This reflects the growing recognition that antidepressants have a prompt onset of action and that failure to respond early in treatment predicts ultimate failure to respond. Also included is a strengthened recommendation for the use of additive antipsychotics (olanzapine, quetiapine, risperidone and aripiprazole) as a first-line option in refractory depression. The guideline on depression in chronic physical health problems mirrors recommendations in the adult guideline and adds specific recommendations for the use of antidepressants in a variety of physical disorders. In this guideline, drug choice is based to some extent on drug interactions and contra-indications. The outcome of this is that less often used drugs (mianserin, mirtazapine, trazodone) are recommended in a number of situations.

Published: 22 April 2010

doi:10.1186/1744-859X-9-S1-S5

Cite this article as: Ohlsen: New guidelines on depression from NICE.

Annals of General Psychiatry 2010 9(Suppl 1):S5.

Institute of Psychiatry, London, UK

Submit your next manuscript to BioMed Central and take full advantage of:

- Convenient online submission

- Thorough peer review

- No space constraints or color figure charges

- Immediate publication on acceptance

- Inclusion in PubMed, CAS, Scopus and Google Scholar

- Research which is freely available for redistribution

Submit your manuscript at www.biomedcentral.com/submit
() Biomed Central 